\title{
Electrochemical Study on Corrosion Inhibition of X52 Steel by Non-ionic Surfactant in Substitute Ocean Water
}

\author{
L.M. Quej-Aké*, A. Contreras and J. Aburto \\ Instituto Mexicano del Petróleo. Eje Central Lázaro Cárdenas Norte 152, Col. San Bartolo \\ Atepehuacan, C. P. 07730, México. \\ *E-mail: lquej@imp.mx
}

doi: $10.20964 / 2018.08 .73$

Received: 6 September 2017 / Accepted: 18 October 2017 / Published: 5 July 2018

\begin{abstract}
The corrosion inhibition for X52 pipeline steel exposed to substitute ocean water adding non-ionic surfactant under two hydrodynamic conditions were studied by using Reynolds number and shear stress near to laminar flow condition. Impedance and Tafel curves were used to assess the electrochemical behavior for X52 steel. Qualitative analysis shown that corrosion rate for X52 steel exposed to corrosive solution without surfactant can be attributed to the rusted by erosion process. Quantitative analysis suggests that laminar flow enhanced the corrosion inhibition for X52 steel when surfactant is added. In addition, limiting current density and adsorption process confirms that the presence of surfactant significantly decreased the corrosion rate as the flow condition also increased. Thermodynamic determination indicated that surfactant electrostatically and physically is adsorbed on X52 steel surface using laminar flow. Calcareous and chloride compounds on X52 steel surface exposed to substitute ocean water could be eliminated by using surfactant.
\end{abstract}

Keywords: laminar flow, impedance, shear stress, adsorption.

\section{FULL TEXT}

(C) 2018 The Authors. Published by ESG (www.electrochemsci.org). This article is an open access article distributed under the terms and conditions of the Creative Commons Attribution license (http://creativecommons.org/licenses/by/4.0/). 